\title{
20. TECTONIC SIGNIFICANCE OF THE SEDIMENTARY COLUMN AT SITE 449 (WESTERN PARECE VELA BASIN), DEEP SEA DRILLING PROJECT LEG 59
}

\author{
Renzo Sartori, Laboratorio di Geologia Marina, Consiglio Nazionale delle Ricerche, 40127 Bologna, Italy
}

\begin{abstract}
At Site 449, middle Miocene carbonate oozes overlie older pelagic clays deposited below the CCD. This anomalous sedimentation is attributed to an uplift of the site with displacement of at least 200 meters. The vertical tectonism occurred about $15 \mathrm{~m} . \mathrm{y}$. ago, roughly synchronous with the cessation of spreading in the Parece Vela Basin and with strong volcanic activity on the West Mariana Ridge. Uplifts of crustal sectors concurrent with the end of spreading and strong volcanic phases might be common in back-arc basins.
\end{abstract}

\section{INTRODUCTION}

According to the concepts of plate stratigraphy, the sedimentary column deposited on a subsiding oceanic crust usually consists of a basal interval of carbonate sediments overlain by pelagic clays (Berger and Winterer, 1974). The superimposition of carbonate-free above carbonate-rich deposits records the sinking of the subsiding sea floor below the carbonate compensation depth (CCD). Hundreds of DSDP holes have demonstrated the general occurrence of this sequence of pelagic sediments.

In a few instances, however, departures from the normal sequence can be observed. Such a case occurs at Site 449, in the Western Parece Vela Basin (Fig. 1), where middle Miocene carbonate and siliceous oozes overlie older pelagic clays. This paper presents some detailed sedimentologic and stratigraphic data on this site and discusses the possible hypotheses for the anomalous reappearance of carbonate sediments: The discussion is mainly focussed on the relationships between CCD and water-sediment interface and on the significance of Site 449 in the evolution of the Parece Vela and other backarc basins.

\section{THE SEDIMENTARY COLUMN OF SITE 449}

A general description of the sediments and depositional units encountered in Hole 449 is presented in the Site 449 report (this volume). In addition, I have made further structural and textural analyses (by gas-volu-

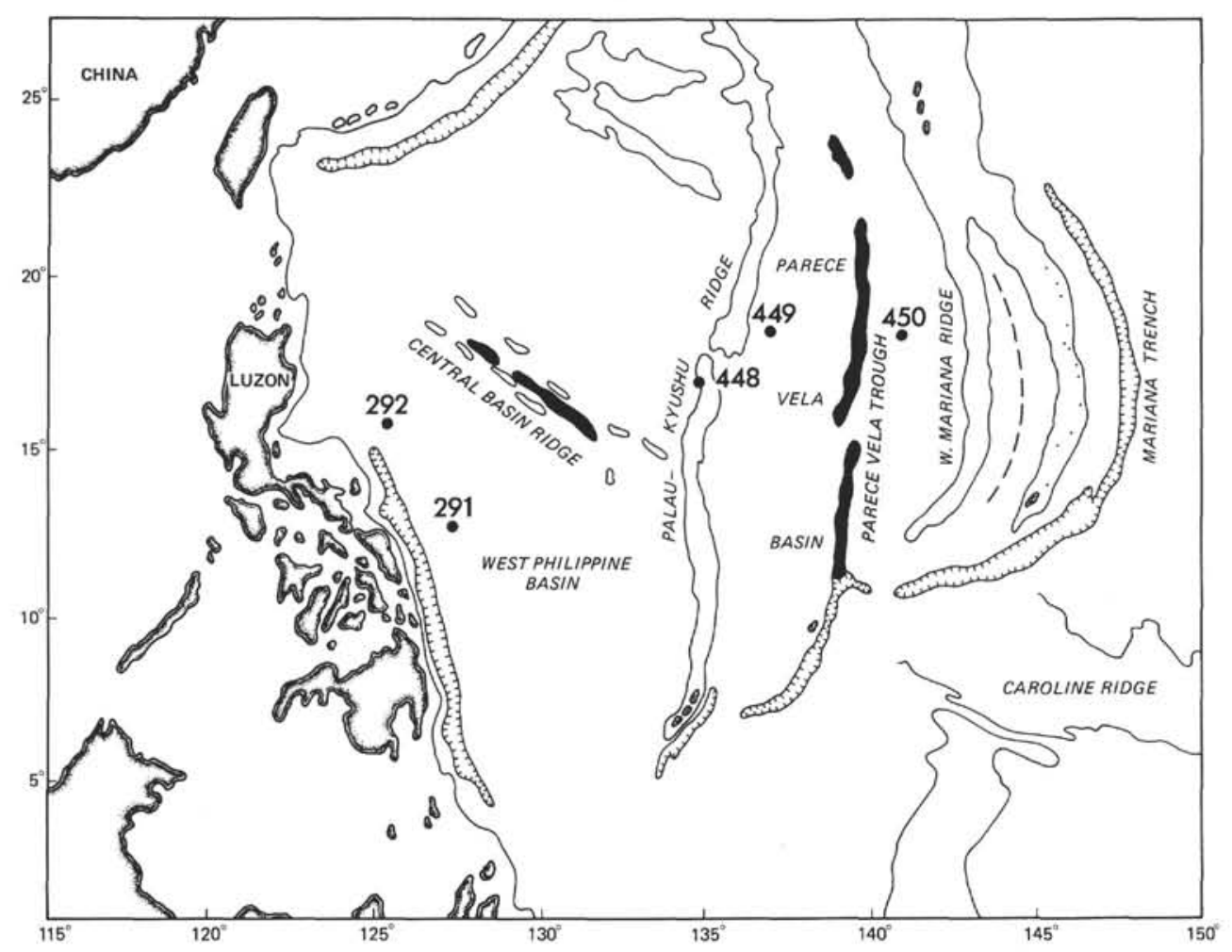

Figure 1. Schematic location of Site 449 and of other DSDP sites discussed in the text. 
metric methods and on smear slides) of numerous samples, many of which are not discussed in the site report. The results are presented in Figures 2 and 3. Figure 2 shows recovery, lithology, and schematic stratigraphy of Hole 449 as well as abundance, preservation, and fossil zones for both nannofossils (Martini, this volume) and radiolarians (Theyer, this volume). The best estimates of the accumulation rates for the different lithologic and stratigraphic intervals are also reported; these were obtained by using the absolute ages for fossilzone boundaries given by Martini (1976). Figure 3 is an enlargement of the middle Miocene portion of the Hole

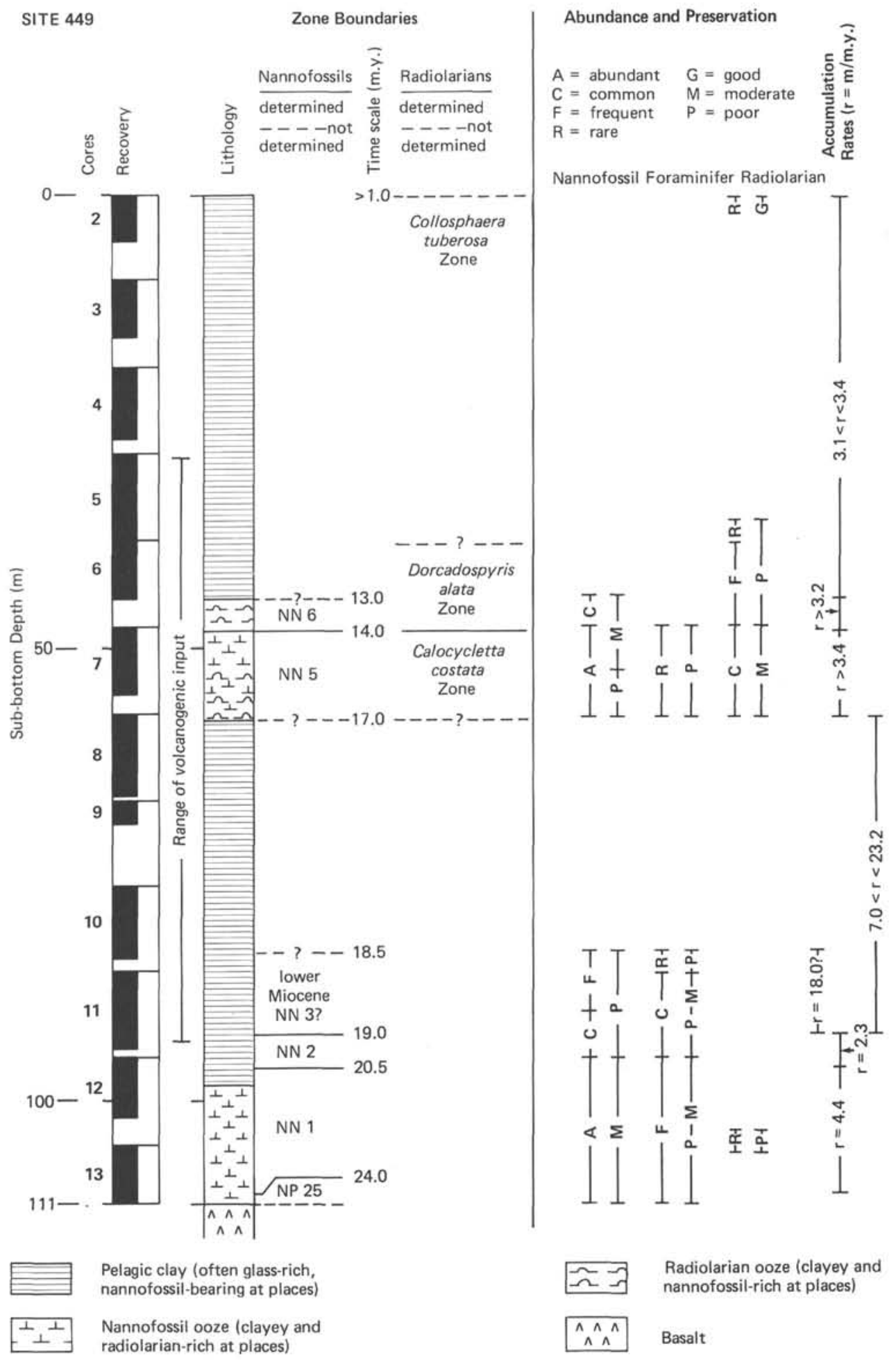

Figure 2. The sedimentary column of Site 449. (Absolute ages for zone boundaries are from E. Martini, 1976.) 


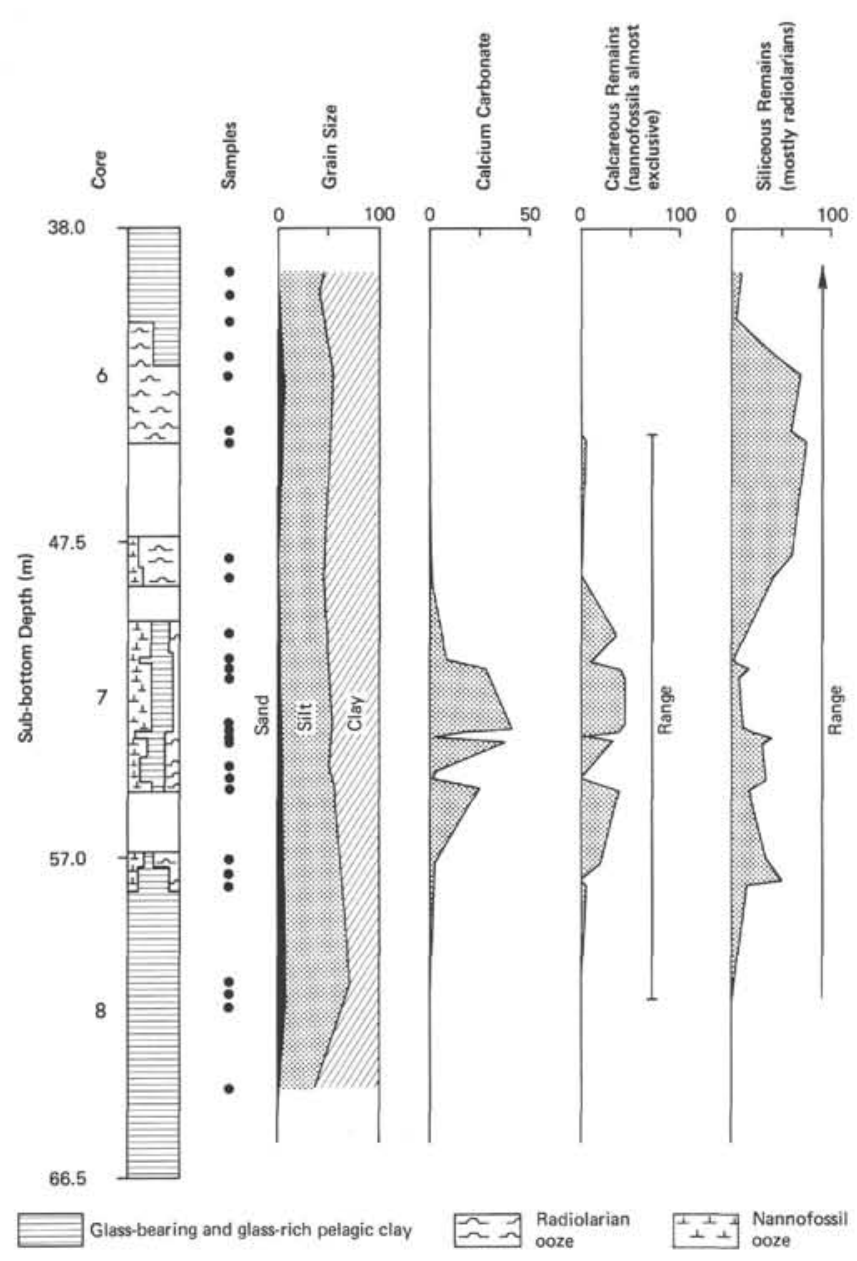

Figure 3. Enlargement of the middle Miocene interval (Cores 6 through 8 ) of Hole 449, with results of the textural and compositional analyses and ranges of distribution of calcareous and siliceous remains.

(Cores 6 through 8). It shows the results of the textural and compositional analyses of the nannofossil and radiolarian oozes and of the pelagic clays immediately overlying and underlying those units. In addition, percentages and ranges of distribution of fossil groups with different skeletal mineralogy (siliceous and calcareous) are reported.

The depositional history of Site 449 can be summarized as follows:

1) accumulation of nannofossil oozes on the basaltic crust during the late Oligocene and very early Miocene (nannofossil Zones NP 25 and part of NN 1);

2) subsidence and progressive deepening of the site across the CCD in the early Miocene (nannofossil Zones from upper NN 1 through NN 3?), accompanied by a lithologic change from nannofossil ooze to pelagic clay (containing scarce and severely etched coccoliths and discoasters) and the eventual disappearance of any carbonate remains;

3) significant volcanic contribution starting from the lower Miocene (end of nannofossil Zone NN 2). The volcanogenic fraction is given by fine glass and pumice fragments and layers and by clay minerals deriving from the transformation of the finest volcaniclastics;
4) reappearance of biogenous (nannofossil and radiolarian) oozes in the early middle Miocene (nannofossil Zones NN 5-NN 6), with a background fraction given by clayey and volcanogenic components;

5) reappearance of pelagic clays above the lower portion of the middle Miocene, with decreasing but still significant volcanic contribution through Core 5;

6) from a post-NN 6 unspecified time (late Miocene?) to the present, deposition of normal pelagic clays with very scarce or absent volcanogenic debris.

\section{DISCUSSION}

The lowermost portion of the sedimentary sequence (upper Oligocene-lower Miocene) can be easily explained in terms of site subsidence, but the middle Miocene intervals of biogenous ooze represent an unusual occurrence. I will critically discuss the different hypotheses that could explain the observed anomaly, supporting my arguments with the data summarized in Figures 2 and 3 as well as with information from other DSDP sites and from the literature.

\section{Reworking of the Biogenous Oozes from Shallower Depths}

Carbonate sediments reworked from above the CCD can be preserved well below that critical depth provided that they are rapidly buried beneath a blanket of pelagic clays protecting the oozes from sea water (Arrhenius, 1963). Such a process occurs in Core 4 of Site 449, where rare and poorly preserved nannofossils of the upper Oligocene are present among pelagic clays postdating the middle Miocene (Site 449 report, this volume). This mechanism, however, cannot account for the middle Miocene interval of biogenous oozes, which does not show any indication of reworking. As shown in Figures 2 and 3 , respectively, the different fossil zones are regularly arranged in a coherent temporal sequence, and no significant changes in grain size appear in Cores 6 through 8 . Moreover, the ages indicated by the nannofossil zones are completely in accordance with those obtained from the radiolarian ones, and the carbonate remains are abundant and moderately well preserved.

\section{Middle Miocene Deepening of the CCD below the Water/Sediment Interface}

The CCD is a dynamic feature of the oceans, whose depth at a given point can fluctuate in response to a number of factors (Arrhenius, 1963; Berger and Winterer, 1974). A deepening of the CCD at Site 449 during the middle Miocene could explain the biogenous oozes of Cores 6 to 8 . Such an event could have been produced by two different causes:

1. Middle Miocene worldwide deepening of the CCD. Analyses of numerous DSDP sites in all the world oceans have evidenced a continuous major shallowing of the CCD from early to late Miocene (Berger, 1972; Van Andel, 1975). This worldwide fluctuation is exactly the contrary of what would be required for explaining the sedimentary sequence at Site 449 .

One may argue that the Philippine Sea is a set of marginal basins somewhat shielded from the open ocean by island-arc chains and that its $C C D$ could be shal- 
lower and independent from that of the open Pacific. Marginal basins can, in fact, have shallow CCD, as recently pointed out by Berger and Winterer (1974). The present CCD of the Philippine Sea, however, does not seem significantly different from that of the adjacent Pacific Ocean. Figure 4 plots the lithology of the mudline core versus water depth for all sites drilled in the Philippine Sea during Legs 6 (Fischer, Heezen, et al., 1971), 31 (Karig, Ingle, et al., 1975), 59 (this volume), and 60 (Hussong, et al., 1978). It appears that carbonate remains are strongly etched below about 4200 meters and disappear at a depth of about 4700 to 4800 meters. The same figure is reported by van Andel (1975) for the present Pacific Ocean outside the equatorial belt of high productivity. According to the geodynamic reconstruction accepted for the Philippine Sea complex (Karig, 1975), we have no reason to infer a greater isolation of the area from the open ocean during the middle Mio-

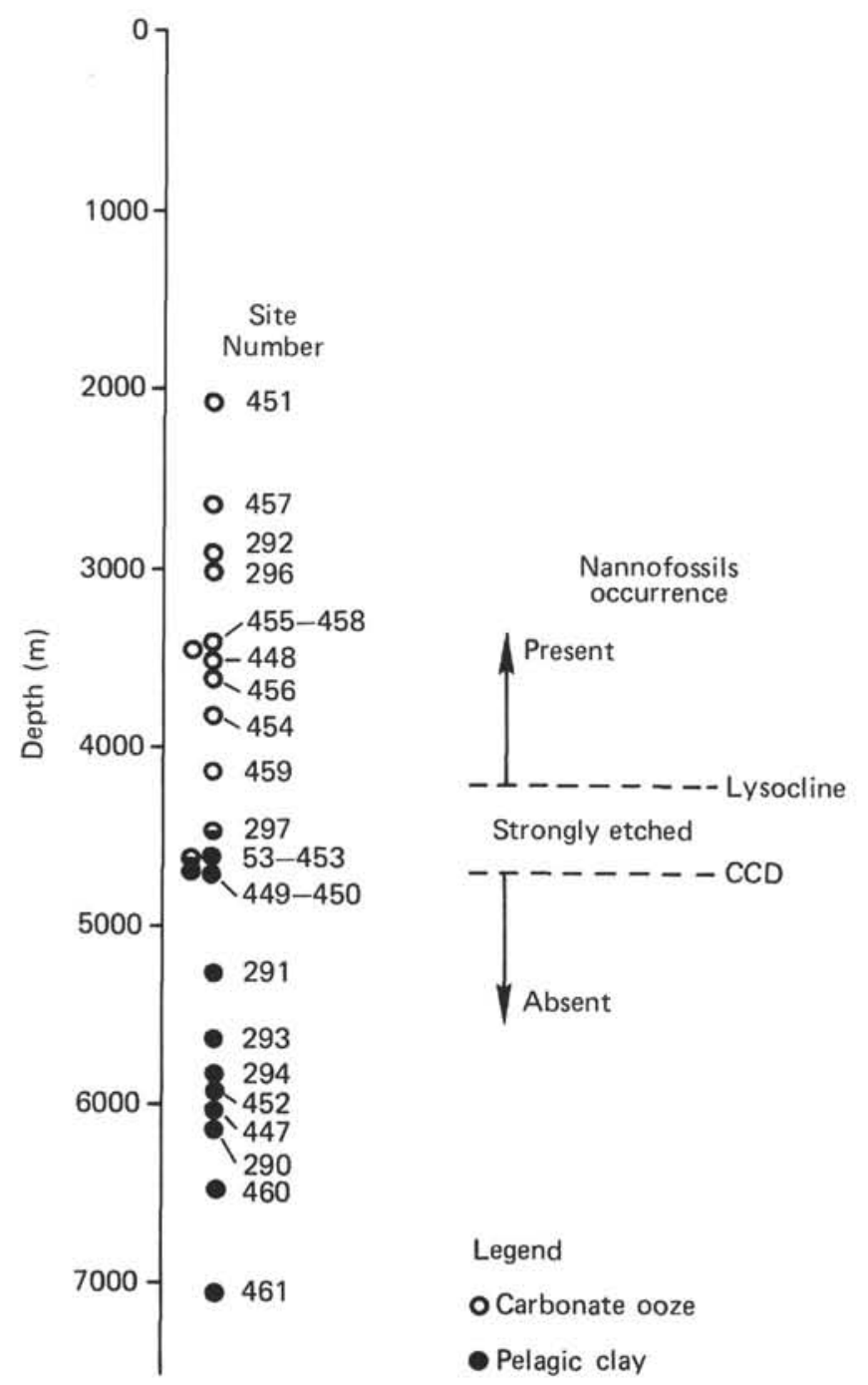

Figure 4. Lithology of the mudline-core tops versus water depth in DSDP holes drilled in the Philippine Sea complex, with presumed lysocline and CCD. cene, because the Mariana Arc had not sundered at that time and the further physiographic barrier of the West Mariana Ridge was not present at all.

2. Site 449 (presently located at about $18^{\circ} \mathrm{N}$ latitude) underwent the influx of the equatorial high-productivity belt and associated currents during the middle Miocene. The Pacific CCD considerably deepens across a belt spanning a few degrees of latitude north and south of the equator. This phenomenon depends on the pattern of the circulation of water masses, which induces an equatorial increase in biologic productivity with associated great amounts of carbonate organisms (Arrhenius, 1963). If Site 449 underwent the influx of this equatorial belt, the associated deeper CCD could account for the reappearance of carbonate oozes. This event could have been produced by a northward drift of the Parece Vela Basin, which caused it to cross the equator at about the middle Miocene; a northward shift of the equatorial high-productivity system at about the same time with subsequent return to its original (and present) location; or a combination of these causes.

Because Leg 59 paleomagnetic evidence for a northward motion of the Philippine Sea Plate during the Neogene is not conclusive (Keating, this volume), let us proceed to discuss the three aforementioned possibilities; there is justification in doing so because we are dealing with a relative movement, and the changes in sedimentation produced by the different causes should be essentially the same (whether the plate moved across the equator or the equatorial belt ran across the Philippine Plate). Mechanisms of high productivity involving the equatorial belt should be reflected in the sedimentary sequences on both a regional and a local scale.

On a regional scale, we should find evidences of increase of middle Miocene productivity at all sites with a latitude (and paleolatitude, assuming a solid drift of the whole Parece Vela Basin) close to that of Site 449. This effect should be particularly notable at those sites where the sedimentation was constantly that of pelagic carbonates, whereas it should pass almost unnoticed at sites of abundant terrigenous and volcaniclastic deposition. Site 448, drilled atop the Palau-Kyushu Ridge (Fig. 1) at almost the same latitude as Site 449 , has a sedimentary column formed by pelagic carbonates (nannofossil oozes) from the upper Oligocene to the upper middle Miocene (nannofossil Zone NN 9), which encompasses the interval of anomalous sedimentation at Site 449. At Site 448, the middle Miocene accumulation rates for the nannofossil Zones NN 5 and NN 6 are not significantly higher than those of older nannofossil oozes, and the preservation of the carbonate skeletons is not good (Site 448 report, this volume). In fact, the accumulation rates are definitely lower than those determined for the Oligocene and the early Miocene (nannofossil Zones NP 25 and NN 1). The same applies to the nannofossil oozes of Site 292 on the Benham Rise at about $16^{\circ} \mathrm{N}$ latitude (Fig. 1). In this hole, the middle Miocene interval displays the lowest accumulation rates of the whole sedimentary sequence, a fact that has been interpreted (following Addicott, 1969) as the result of a climatically 
induced marked decrease of the productivity of the whole Pacific Ocean at that time (Ingle, Karig, et al., 1975b).

On a local scale, we should find accumulation rates increasing toward the middle-Miocene interval of biogenous oozes because of presumed increase of productivity and the lithologic change from pelagic clays to nannofossil oozes. The latter should have by themselves higher accumulation rates than the pelagic clays, which are residual products of dissolution of the carbonate fraction. The accumulation rates estimated for Site 449 (Fig. 2) contradict this assumption. We observe high figures for the lower Miocene pelagic clays, a fact that reflects the importance of the volcanogenic contribution starting above nannofossil Zone NN 2, but we also observe that these rates decrease in the overlying nannofossil ooze intervals (NN 5 and NN 6). The accumulation rates for the Miocene of Site 449 should depend mostly on the importance and range of the volcanogenic input, which spans the lower to upper Miocene. This contribution should also be reflected by the mineralogic composition of the pelagic clays (Balshaw, this volume). Also taking into account this additional supply, the rates for the middle Miocene nannofossil oozes appear comparable with (if not lower than) those for the equivalent lithologies of the lower Miocene. This means a net decrease in productivity during the middle Miocene, which is again contrary to the assumed hypothesis of involvement of the equatorial belt in the anomalous sedimentation.

\section{Middle Miocene Uplift of Site 449}

The inadequacy of the hypotheses previously discussed leaves the uplift of the site as the only possible mechanism for explaining the anomalous sedimentation of Site 449. Although we do not have any direct proof of this process, all the observed facts are consistent with it. In particular:

1) The middle Miocene anomalous event did not occur at other sites of comparable latitude, which points to the fact that the process has affected limited crustal blocks within the Philippine Sea.

2) The accumulation rates of the middle Miocene nannofossil oozes of Site $\mathbf{4 4 9}$ are lower than those of the underlying pelagic clays. In a quiet physiographic setting the opposite trend should occur. The decrease of accumulation rates is consistent with an uplift of the site which would produce a physiographic high topping above the CCD. Apart from the sedimentologic change, such an elevated environment would no longer be reached by most of the sediments driven by density and turbidity currents along the water/sediment interface. The accumulation rates should drop accordingly. Site 449 is presently located on a structural high in a portion of the Parece Vela Basin characterized by extremely rugged topography.

3) Nannofossils and radiolarians suddenly appear together at the beginning of nannofossil Zone NN 5 (Fig. 2). Upward in the hole, nannofossils disappear first whereas radiolarians occur for many more meters. This asymmetrical pattern of appearance-disappearance of different solution-resistant fossil groups may in- dicate a very rapid onset of the anomalous sedimentation with a slow return to normal conditions. The rapid onset of biogenic sedimentation would again be consistent with an uplift of the site, a movement that could be orders of magnitude more rapid than drifting of the site or large-scale fluctuations of the CCD. The slow disappearance of the previously mentioned fossil groups could reflect either a slow post middle Miocene subsidence of the site or the progressive shallowing of the CCD toward the end of the Miocene, which happened in the Pacific Ocean according to van Andel (1975).

4) Nannofossil- and radiolarian-poor layers inside the NN 5 to NN 6 interval (Fig. 3) might represent either second-order (climatic?) fluctuation of the CCD or layers with higher volcanogenic input, in which the glass is almost completely altered to clay minerals.

\section{AMOUNT AND SIGNIFICANCE OF THE UPLIFT}

The temporal limits of the tectonic event are obviously set by the appearance of nannofossils close to the top of Core 8 . The age boundaries for the nannofossil Zone NN 5 are 14.0 to 17.0 m.y. (Martini, 1976), and inside this age-span we have to place the uplift of the site.

As regards the possible amount of uplift, we can arrive at some first-approximation minimum figures by employing the "paleo-CCDs" reconstructed by van Andel (1975). Using the curves of this researcher for latitudes outside the equatorial belt of high productivity, we can fix two "paleo-CCDs" when the carbonate organisms first disappeared and subsequently reappeared. The difference between these figures (about 4200 and $4000 \mathrm{~m}$ ) gives the minimum displacement caused by the uplift, i.e. about 200 meters.

According to the magnetic anomalies and to the paleontologic ages of the oceanic crust drilled during Legs 6 (Fisher, Heezen, et al., 1971) and 59 (this volume), the spreading history of the presently inactive Parece Vela Basin started in the late Oligocene and ended in the middle Miocene (Site 449 report, this volume). The fossilspreading center is reputed to be the Parece Vela Rift, a system of north-south trending deep troughs bisecting the basin.

The middle Miocene strata of Site 450, drilled in the eastern half of the basin (Fig. 1), shows evidence of tectonic activity in the basin (basaltic intrusions) and of strong volcanism on the frontal arc, with thick deposition of penecontemporaneous turbiditic tuffs and hyaloclastites (Site 450 report, this volume). The uplift at Site 449 , which also occurred in the middle Miocene, could thus be related to a vertical tectonism contemporaneous with or slightly postdating the end of the distensive phases that formed the basin.

The close temporal correspondence between vertical tectonism, end of spreading, and strong volcanic activity on the arc found in the Parece Vela Basin might suggest that all these events are expressions of a general pattern of tectonic evolution for back-arc basins. If this holds true, uplifts could be relatively frequent in presently inactive basins. Uplifts of previously subsided crustal blocks, however, are not likely to be detected everywhere, because the produced change in depth has to 
be great enough to induce some recognizable anomaly in the sediments. Another example of uplift reflected in anomalous sedimentation might be Site 291 (Fig. 1), drilled during DSDP Leg 31 in the West Philippine Basin (though differently interpreted by Ingle, Karig, et al., 1975a). Here a middle to late Oligocene unit of nannofossil oozes overlies older pelagic clays, which rest on the basaltic basement. One of the hypotheses for the genesis of the West Philippine Sea is that it derived from spreading along the Central Basin Ridge and behind the PalauKyushu Ridge volcanic arc (Site 447 report, this volume). The assumed cessation of spreading along the Central Basin Ridge and the beginning of strong volcanic activity on the Palau-Kyushu Ridge is middle late Oligocene, i.e., more or less synchronous with the appearance of the anomalous nannofossil oozes at Site 291. This might again reflect a crustal uplift with the same significance as that detected at Site 449.

\section{ACKNOWLEDGMENTS}

I wish to thank Prof. A. Castellarin for the critical reading of the manuscript and Mr. M. Mengoli for the gas-volumetric analyses. G. Zini drew the illustrations.

\section{REFERENCES}

Addicott, W. O., 1969. Tertiary climatic changes in the marginal northeastern Pacific Ocean. Science, 165:583.
Arrhenius, G., 1963. Pelagic sediments. In Hill, M. N. (Ed.), The Sea (Vol. 3): New York (Interscience), 655-727.

Berger, W. H., 1972. Deep sea carbonates: dissolution facies and age-depth constancy. Nature, 236:392-395.

Berger, W. H., and Winterer, E. L., Plate stratigraphy and the fluctuating carbonate line. In Hsü, K. J., and Jenkins, H. C. (Eds.), Pelagic Sedimentation: on Land and under the Sea: Oxford (Blackwell Scientific Publications), Special Publication International Association of Sedimentologists, no. 1, pp. 11-48.

Fischer, A. G., Heezen, B. C., et al., 1971. Init. Repts. DSDP, 6: Washington (U.S. Govt. Printing Office).

Hussong, D., Uyeda, S., Blanchet, R., 1978. Leg 60 ends in Guam. Geotimes, 23:19-22

Ingle, J. C., Jr., Karig, D. E., et al., 1975a. Site 291. In Karig, D. E., Ingle, J. C., Jr., et al., Init. Repts. DSDP, 31: Washington (U.S. Govt. Printing Office), 49-65.

, 1975b. Site 292. In Karig, D. E., Ingle, J. C., Jr., et al., Init. Repts. DSDP, 31: Washington (U.S. Govt. Printing Office), 67-129.

Karig, D. E., 1975. Basin genesis in the Philippine Sea. In Karig, D. E., Ingle, J. C., Jr., et al., Init. Repts. DSDP, 31: Washington (U.S. Govt. Printing Office), 857-879.

Karig, D. E., Ingle, J. C., Jr., et al., 1975. Init. Repts. DSDP, 31: Washington (U.S. Govt. Printing Office).

Martini, E., 1976. Cretaceous to Recent calcareous nannoplankton from the central Pacific Ocean (DSDP Leg 33). In Schlanger, S. O., Jackson, E. D., et al., Init. Repts. DSDP, 31: Washington (U.S. Govt. Printing Office), 383-423.

van Andel, T. H., 1975. Mesozoic/Cenozoic calcite compensation depth and the global distribution of calcareous sediments. Earth Planet. Sci. Lett., 26:187-194. 